\title{
An experimental study of high-hydrogen welding processes
}

\author{
Dariusz Fydrych ${ }^{\bowtie}$, Jerzy Łabanowski \\ Gdańsk University of Technology (GUT), Narutowicza 11/12, 80-233 Gdańsk, Poland \\ Corresponding author: darfydry@pg.gda.pl
}

Submitted: 20 May 2015; Accepted: 3 October 2015; Available On-line: 13 N ovember 2015

\begin{abstract}
This paper presents investigation results of determination of the diffusible hydrogen content in deposited metal obtained by means of two most often used methods-the glycerin method and the mercury method. Relation has been defined between results of those methods in the area characteristic of low-hydrogen as well as high-hydrogen welding processes. Relations available in the literature do not include the diffusible hydrogen content in deposited metal greater than $35 \mathrm{ml} / 100 \mathrm{~g}$. Extending the scope of analysis of the diffusible hydrogen quantity to an $80 \mathrm{ml} / 100 \mathrm{~g}$ level considerably simplifies carrying out the steel weldability assessment with the use of high-hydrogen processes and with welding in water environment.
\end{abstract}

KEYWORDS: Diffusible hydrogen; Glycerin method; Mercury method; Underwater welding; Weldability

Citation / Cómo citar este artículo: Fydrych, D., Labanowski, J. (2015) "An experimental study of high-hydrogen welding processes". Rev. Metal. 51(4): e055. doi: http://dx.doi.org/10.3989/revmetalm.055.

RESUMEN: Estudio experimental de procesos de soldadura con alto contenido en hidrógeno. Este trabajo presenta los resultados de una investigación sobre la determinación del contenido de hidrógeno difusible en el material aportado mediante dos métodos: el de la glicerina (el más utilizado) y el del mercurio. El contenido de dicho hidrógeno se ha definido a partir de los resultados de esos métodos en una zona con bajo contenido en hidrógeno, así como procesos de soldadura con alto contenido en hidrógeno. No hay datos disponibles en la literatura para contenidos de hidrógeno difusible en metal depositado mayores de $35 \mathrm{ml} / 100 \mathrm{~g}$. Ampliando el análisis de la cantidad de dicho hidrógeno hasta los $80 \mathrm{ml} / 100 \mathrm{~g}$, se simplifica considerablemente la realización de ensayos de soldabilidad del acero en procesos de alto contenido en hidrógeno así como en la soldadura en medio acuoso.

PALABRAS CLAVE: Hidrógeno difusible; Método de la glicerina; Método del mercurio; Soldadura subacuática; Soldabilidad

Copyright: (C) 2015 CSIC. This is an open-access article distributed under the terms of the Creative Commons Attribution-Non Commercial (by-nc) Spain 3.0 License.

\section{INTRODUCTION}

Excessive content of hydrogen in the steel welded joints causes decrease of metal plasticity and is a reason of formation of welding defects and imperfections, such as porosity and cold cracks (Pokhodnya et al., 2004; Kozak, 2011; Pańcikiewicz et al., 2013; Kurji and Coniglio, 2015). Therefore, problems connected with measurements of hydrogen content in joints have been a field of interest for many years (Padhy et al., 2015a, Kühn et al., 2013). The total volume of hydrogen introduced into a welded joint 
may be divided into the diffusible hydrogen dissolved in steel in an atom or ion state and released from it in ambient temperature, and the residual hydrogen, permanently trapped in the steel microstructure without possibility of releasing in ambient temperature (ISO 3690, 2012; Fydrych and Labanowski, 2012; Padhy and Komizo, 2013).

In practice, the most often met case is determination of the diffusible hydrogen content in deposited metal and on this basis drawing conclusions about the hydrogen level of the whole joint. Determination of the diffusible hydrogen content in joint can be carried out in order to classify welding filler materials, indicate hydrogen sources, determine the degree of susceptibility to cold cracking (Pokhodnya et al., 2004; Kotecki, 1992; Fydrych and Labanowski, 2012). Results of such investigations may also be used as input data for calculations of preheating and postweld treatment temperature (Kotecki, 1994; Fydrych and Łabanowski, 2012). Taking into account the key role of hydrogen in the cold cracking formation process, practically all steel weldability investigations are carried out with simultaneous control of the diffusible hydrogen content in deposited metal (Pokhodnya et al., 2004; Kozak, 2011; Fydrych et al., 2013).

When the aim of investigation is classifying the filler materials, they should be subjected to identical test procedures, for instance constant drying conditions and carrying out test weld beads with the same values of welding parameters. In a situation when the tests are to be used for determining the influence of filler metal storage conditions and welding conditions on the deposited metal hydrogen level, those conditions may be changed in an arbitrary manner, but they must be specified for communicated test results (ISO 3690, 2012).

There are many different methods of determining the diffusible hydrogen content in a welded joint. Their common characteristic is using different working liquids where welded samples are immersed and hydrogen is collected in the closed space over the liquid. The following methods: glycerin, water, paraffin, alcohol, silicone oil method are used under normal pressure and the mercury method is used under reduced pressure. Results obtained with these methods (except the mercury method) are encumbered with an error, as hydrogen may dissolve to a certain degree in the working liquids. Therefore, such results are not reliable at a low level of diffusible hydrogen content (ISO 3690, 2012; Kotecki, 1992; Padhy and Komizo, 2013). There are also other, less frequently applied, methods of determining the total hydrogen content, for instance the vacuum extraction method carried out at a $600-650^{\circ} \mathrm{C}$ temperature and the method of gas analysis during the complete combustion of the sample. Besides, attempts are being made to determine the diffusible hydrogen content by means of mathematical models and computer techniques (Karkhin and Levchenko, 2008).
The glycerin and mercury methods are most often used due to great experience and simplicity of their application. The mercury method is recommended by the relevant standard as a reference method for calibration of alternative methods (ISO 3690, 2012; Kotecki, 1992; Padhy and Komizo, 2013). An advantage of the mercury method in comparison with the glycerin method is greater measurement accuracy and better repeatability of results. Such repeatability has been confirmed in inter-laboratory tests showing differences in the diffusible hydrogen content measurements not greater than $2 \mathrm{ml} / 100 \mathrm{~g}$ of deposited metal (Kotecki, 1992). The most important disadvantage of the mercury method is toxicity of mercury (ISO 3690, 2012; Kotecki, 1992; López et al., 2014; López et al., 2015).

Differences in the results obtained with the glycerin and mercury methods are caused mainly by different solubility of hydrogen in the working liquid. An impact of that effect can be predicted with making use of relevant relations between results of the glycerin and mercury methods (Pokhodnya et al., 2004; ISO 3690, 2012; Kotecki, 1992). In view of a great number of factors influencing the accuracy of diffusible hydrogen content measurements, it is recommended that individual relations should be determined by laboratories for those alternative methods (Fydrych and Labanowski, 2012). Table 1 presents a set of equations describing relations, given in literature, between results of the glycerin and mercury methods, and Fig. 1 shows their graphical interpretation. Similar relations have been also developed for other alternative methods (Pokhodnya et al., 2004; Ström and Elvander, 2004; Kannengiesser and Tiersch, 2010; Padhy et al., 2015b).

Although the relations presented in Table 1 are different in the form and in directional coefficient values, their graphical representations show that they are similar and that there is very little difference between them. Unfortunately, capability of recalculating the results of discussed methods is limited to the level of $35 \mathrm{ml} / 100 \mathrm{~g}$ of diffusible hydrogen in deposited metal, characteristic of welding by conventional methods (Pokhodnya et al., 2004; Kotecki, 1992). When determination of the hydrogen content in deposited metal from high-hydrogen welding processes is required, such as welding with

TABLE 1. Relations between results of the glycerin and mercury methods

\begin{tabular}{ll}
\hline Relation & \multicolumn{1}{c}{ Literature source } \\
\hline $\mathrm{HDgl}=0.64 \times \mathrm{HDme}-0.93$ & Coe, 1972 \\
$\mathrm{HDgl}=0.67 \times \mathrm{Hme}-0.80$ & Anon., 1974 \\
$\mathrm{HDgl}=0.79 \times$ HDme -1.73 & Anon., 1986 \\
$\mathrm{HDgl}=0.658 \times$ HDme & Grela and Mazur, 2002 \\
\hline
\end{tabular}

HDgl - glycerin method, HDme - mercury method. 


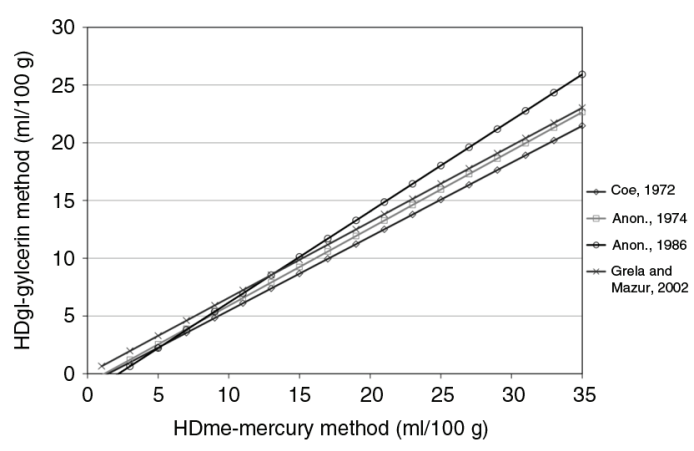

FIGURE 1. Comparison of results of the glycerin and mercury methods, based on literature data.

rutile, cellulose and acid electrodes $(35 \mathrm{ml} / 100 \mathrm{~g}$ of diffusible hydrogen) or from wet welding in water environment (up to $90 \mathrm{ml} / 100 \mathrm{~g}$ of diffusible hydrogen), the existing relations cannot be used. Extrapolation beyond the tested range of $35 \mathrm{ml} / 100 \mathrm{~g}$ may lead to erroneous results due to possible non-linearity of the relations.

The aim of the undertaken investigations was to determine relations between results of the glycerin and mercury methods in the range up to $80 \mathrm{ml} / 100 \mathrm{~g}$ of diffusible hydrogen. This required diffusible hydrogen content in deposited metal to be determined by two discussed methods in the conditions corresponding to the low-hydrogen and high-hydrogen welding processes and also the respective statistical analyses to be carried out.

\section{MATERIALS AND METHODS}

In order to obtain results in a maximum width of the range, the diffusible hydrogen content was measured in the deposited metal from six commercial types of electrodes with different (rutile, acid and basic) coating. The test weld beads were carried out with electrodes in the as received conditions, artificially moistened and also in the wet welding conditions, at $0.5 \mathrm{~m}$ depth under water. Electrodes were moistened in a climatic chamber in the water vapor atmosphere, at $50{ }^{\circ} \mathrm{C}$ temperature and $95 \%$ relative humidity, for a time from 5 minutes to 14 hours.

The weld beads were made on $4 \times 20 \times 120 \mathrm{~mm}$ specimens (glycerin method) and on $10 \times 15 \times 30 \mathrm{~mm}$ specimens (mercury method) from the S235JR mild steel. Before welding specimens were degassed at $650^{\circ} \mathrm{C}$ temperature for 1 hour. Table 2 presents chemical composition of plate and Table 3 shows chemical

TABLE 2. Chemical composition of S235JR steel (wt-\%)

\begin{tabular}{lccccc}
\hline $\mathbf{C}^{*}$ & $\mathbf{M n *}$ & $\mathbf{P}^{*}$ & $\mathbf{S}^{*}$ & $\mathbf{N}^{*}$ & $\mathbf{C u}^{*}$ \\
\hline 0.17 & 1.4 & 0.035 & 0.045 & 0.012 & 0.55 \\
\hline * $_{\max }$ & & & &
\end{tabular}

composition and mechanical properties of deposited metal from the electrodes (all electrodes of $4 \mathrm{~mm}$ diameter).

Determination of the diffusible hydrogen content with the glycerin and mercury methods was carried out in accordance with standard procedures (BN-64/4130-01, 1971; ISO 3690, 2012) requiring making the test weld beads, placing the sample in the test stand measurement vessel, extraction of the diffusible hydrogen at $45{ }^{\circ} \mathrm{C}$ temperature after 72 hours of exposure in the working liquid, recalculation of the gas volume results readout into gas volume in normal temperature and pressure. Figure 2 presents measurement stands for the glycerin and mercury method. Before welding the sample was weighed with the accuracy of $0.01 \mathrm{~g}$. The sample was placed in copper fixture and then weld bead was deposited with a short arc. After completion of welding the slag was removed and the sample was quenched in water at $20^{\circ} \mathrm{C}$. After 30 seconds the sample was cleaned, dried and placed in apparatus. The time from end of welding the sample to beginning the hydrogen content measurements did not exceed 2 minutes. During extraction the temperature of stand was measured and after test hydrogen volume in burette, temperature and pressure were noted. After removal from measurement vessel the sample was cleaned, dried and weighed to determine the amount of deposited metal. Recounting of results to normal conditions was made according to formula from BN-64/4130-01 (1971) and ISO 3690 (2012) standards. The glycerin solution was changed every two weeks according to recommendation (Quintana, 1984).

\section{RESULTS}

In accordance with the assumed scope of investigation, seventeen series of tests were carried out. One test series consisted of 3 tests for each of the two diffusible hydrogen determination methods applied. All together 102 test weld beads were carried out (Fig. 3). Each weld bead was made with a separate electrode, in order to avoid drying the electrode coating by the arc heat (Świerczyńska et al., 2012). Welding was performed with current recommended by the manufacturer (approximately $160 \mathrm{~A}$ ) for the $4 \mathrm{~mm}$ diameter electrodes used. Results of determination of diffusible hydrogen content, together with the experiment conditions are presented in Table 4 as mean values of three measurements. In accordance with expectations, in all tests the results of the glycerin method were lower than those of the mercury method. This is particularly visible for weld beads made with basic electrodes in the as received condition (measurements 9,12 and 15 ). Standard deviation values of the glycerin method are larger than those of mercury method. The determined standard deviations are in comparable order of magnitude to 
TABLE 3. Chemical composition and mechanical properties of coated electrodes deposited metal

\begin{tabular}{|c|c|c|c|c|c|c|c|}
\hline Electrode designation & Coating type & $\mathrm{C}(\%)$ & Si $(\%)$ & Mn (\%) & $\operatorname{Re}(\mathrm{MPa})$ & Rm (MPa) & A5 (\%) \\
\hline ER 2.46 (E 382 RB 2) & Rutile & 0.08 & 0.15 & 0.60 & $>410$ & $490-560$ & $24-30$ \\
\hline ER 1.46 (E 380 RC 1) & Rutile & 0.08 & 0.20 & 0.50 & $>380$ & $480-570$ & $>22$ \\
\hline EA 1.46 (E 350 RA 2) & Acid & 0.07 & 0.06 & 0.40 & $>370$ & $450-510$ & $24-30$ \\
\hline OK 75.75 (E $694 \mathrm{Mn}_{2}$ NiCrMo B 42 H5) & Basic & 0.06 & 0.35 & 1.7 & 755 & 820 & 20 \\
\hline OK 48.08 (E 465 1Ni B 32 H5) & Basic & 0.06 & 0.4 & 1.2 & 480 & 560 & 26 \\
\hline EB 1.46 (E 383 B 42) & Basic & 0.07 & 0.4 & 0.8 & $>400$ & $500-580$ & $24-32$ \\
\hline
\end{tabular}

(a)

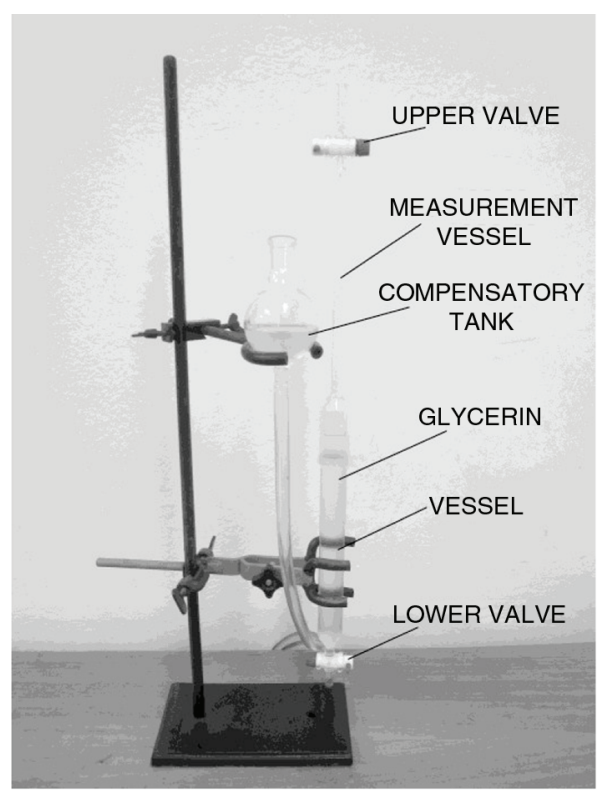

(b)

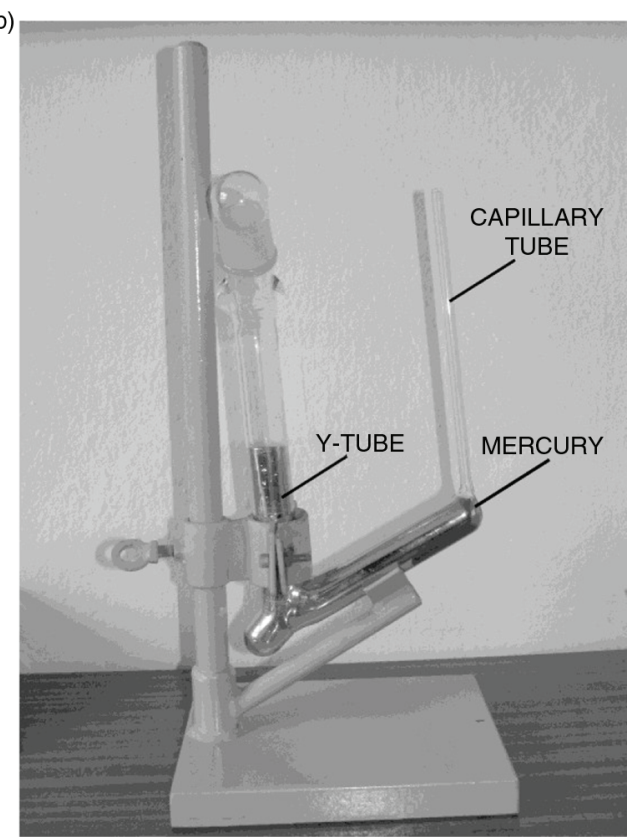

FIGURE 2. Test stands for determination of the diffusible hydrogen content in deposited metal: (a) glycerin method and (b) mercury method. results of other authors (Kannengiesser and Tiersch, 2010; Padhy et al., 2012; Padhy et al., 2015b; Kotecki, 1992; Pokhodnya et al., 2004).

With the use of results presented in Table 4, statistical analyses were performed in Statistica software package for a significance level of $\alpha=0.05$ (Stanisz, 2007). The standard method of least squares linear regression was used to ascertain the functional relationship between the hydrogen contents measured by mercury and glycerin methods in the form of reference-equivalence-function $\mathrm{y}=\mathrm{mx}+\mathrm{n}$.

The regression analysis of test results was carried out twice: determining the HDme $=\mathrm{f}(\mathrm{HDgl})$ function, which may be used in practice (model I), and the $\mathrm{HDgl}=\mathrm{f}(\mathrm{HDme})$ function (model II). The second equation was determined in order to compare the test results with relations described in literature. The following regression equations were formulated from the analysis results:

HDme $=1.21 \times \mathrm{HDgl}+2.60$ model I

$\mathrm{HDgl}=0.81 \times \mathrm{HDme}-1.71$ model II

where:

HDme-hydrogen content in deposited metal determined with mercury method $(\mathrm{ml} / 100 \mathrm{~g})$,

HDgl-hydrogen content in deposited metal determined with glycerin method $(\mathrm{ml} / 100 \mathrm{~g})$.

A relation is statistically significant at a high value of the adjusted coefficient of determination $\left(\mathrm{R}^{2} \mathrm{adj}=0.98\right)$. Difference between diffusible hydrogen content determined experimentally with mercury method and that calculated from model $\mathrm{I}$ is presented in Fig. 4.

The condition of recognising a model as correct is compatibility of the distribution of raw residuals generated by the model with normal distribution (Stanisz, 2007). Results of the experiments, values obtained from model I and raw residuals generated by that model are given in Table 5. As the value of critical significance level $\mathrm{p}=0.306$ (the Shapiro-Wilk test) is greater than the assumed significance level $\alpha=0.05$, there is no basis for rejection of the null hypothesis regarding normality of distribution of the model residuals. 
(a)

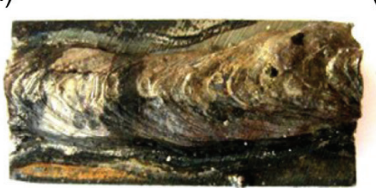

(b)

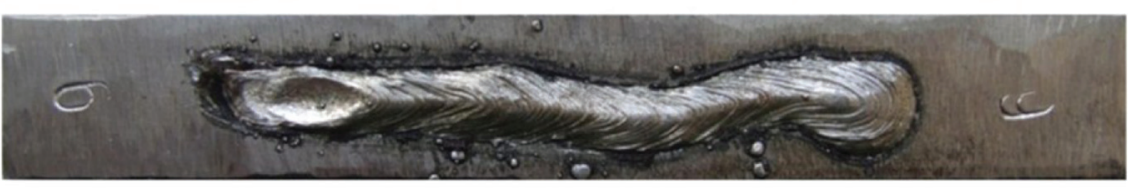

FIGURE 3. View of exemplary test weld beads: (a) mercury method (EB1.46 electrode, air welding) and (b) glycerin method (ER2.46 electrode, underwater wet welding).

\section{DISCUSSION}

Note in the standard (ISO 3690, 2012) allowing alternative test methods to be used for determination of diffusible hydrogen content in deposited metal admits the use of glycerin method instead of more difficult in practical application mercury method. However, this is conditional on the knowledge of relation between results of those methods due to different hydrogen solubility in the two media. In a situation of determining low hydrogen contents, below $5 \mathrm{ml} / 100 \mathrm{~g}$, only the mercury method should be used.

The need to perform supplementary investigation for checking the relation between results of the glycerin and mercury methods was caused by narrow validity range (up to $35 \mathrm{ml} / 100 \mathrm{~g}$ ) of the existing equations. This narrow range of applicability limited the use of those equations for determining the diffusible hydrogen content in deposited metal obtained from high-hydrogen welding processes.

The planned experiment allowed to determine the diffusible hydrogen content in the range from 6 to $80 \mathrm{ml}$ per $100 \mathrm{~g}$ of deposited metal. The developed equation is characterised by a high value $\left(\mathrm{R}^{2} \mathrm{adj}=0.98\right)$ of adjusted squared correlation coefficient and distribution of the generated raw residuals is statistically estimated as compatible with normal distribution. Development of model II, $\mathrm{HDgl}=\mathrm{f}(\mathrm{HDme})$, made it possible to compare the results of the two discussed diffusible hydrogen content determination methods with results obtained in other laboratories. Figure 5 presents the newdeveloped expression, model II, describing relation

TABLE 4. Results of determination of the diffusible hydrogen content in deposited metal by glycerin method $(\mathrm{ml} / 100 \mathrm{~g})$ and mercury method $(\mathrm{ml} / 100 \mathrm{~g})$

\begin{tabular}{|c|c|c|c|c|c|c|}
\hline No. & $\begin{array}{c}\text { Electrode } \\
\text { designation }\end{array}$ & Electrode condition & $\begin{array}{l}\text { Average diffusible } \\
\text { hydrogen content* }\end{array}$ & $\begin{array}{c}\text { Standard deviation of } \\
\text { diffusible hydrogen } \\
\text { content* }\end{array}$ & $\begin{array}{c}\text { Average diffusible } \\
\text { hydrogen content** }\end{array}$ & $\begin{array}{c}\text { Standard deviation of } \\
\text { diffusible hydrogen } \\
\text { content }{ }^{* *}\end{array}$ \\
\hline 1 & ER 2.46 & As received & 29.32 & 1.382 & 36.75 & 1.186 \\
\hline 2 & ER 2.46 & 5 min moistening & 41.45 & 3.374 & 48.40 & 1.814 \\
\hline 3 & ER 2.46 & 10 min moistening & 42.08 & 4.114 & 49.24 & 1.555 \\
\hline 4 & ER 2.46 & 30 min moistening & 47.37 & 2.207 & 60.40 & 2.152 \\
\hline 5 & ER 2.46 & $12 \mathrm{~h}$ moistening & 58.71 & 8.549 & 79.09 & 2.882 \\
\hline 6 & ER 2.46 & Under water & 39.16 & 3.611 & 47.86 & 2.574 \\
\hline 7 & ER 1.46 & As received & 32.34 & 3.461 & 39.75 & 1.426 \\
\hline 8 & EA 1.46 & As received & 59.10 & 5.927 & 77.98 & 3.126 \\
\hline 9 & OK 75.75 & As received & 4.40 & 2.125 & 6.53 & 0.176 \\
\hline 10 & OK 75.75 & $7 \mathrm{~h}$ moistening & 6.16 & 2.382 & 12.51 & 0.563 \\
\hline 11 & OK 75.75 & $14 \mathrm{~h}$ moistening & 12.73 & 1.255 & 15.92 & 0.364 \\
\hline 12 & OK 48.08 & As received & 1.66 & 1.161 & 6.08 & 0.116 \\
\hline 13 & OK 48.08 & $7 \mathrm{~h}$ moistening & 7.46 & 1.311 & 8.21 & 0.377 \\
\hline 14 & OK 48.08 & $14 \mathrm{~h}$ moistening & 12.19 & 1.929 & 22.42 & 1.211 \\
\hline 15 & EB 1.46 & As received & 2.29 & 1.321 & 7.12 & 0.18 \\
\hline 16 & EB 1.46 & $7 \mathrm{~h}$ moistening & 7.30 & 2.052 & 14.21 & 0.310 \\
\hline 17 & EB 1.46 & $14 \mathrm{~h}$ moistening & 23.39 & 2.410 & 29.56 & 1.628 \\
\hline
\end{tabular}

${ }^{*}$ glycerin method $(\mathrm{ml} / 100 \mathrm{~g}), * *$ mercury method $(\mathrm{ml} / 100 \mathrm{~g})$. 


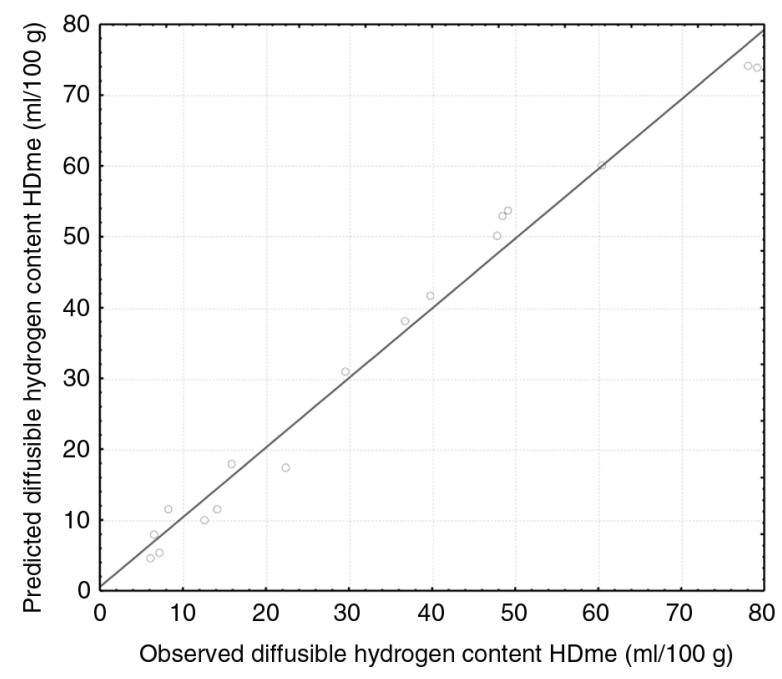

FIGURE 4. Relation of experimentally determined HDme values to those calculated from model I.

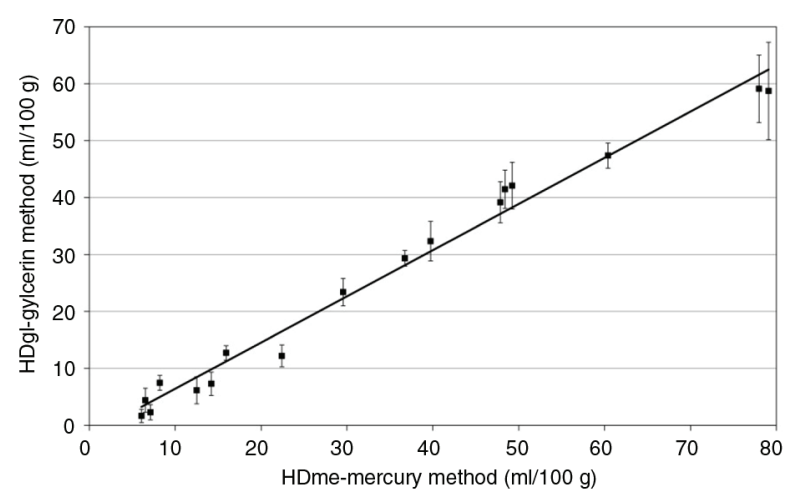

Figure 5. Comparison of the diffusible hydrogen content obtained with the mercury method and glycerin method in the up to $80 \mathrm{ml} / 100 \mathrm{~g}$ range.

between diffusible hydrogen contents obtained from the mercury method and glycerin method in the up to $80 \mathrm{ml} / 100 \mathrm{~g}$ range.

The developed equation is, in the hydrogen content up to $35 \mathrm{ml} / 100 \mathrm{~g}$ range, close to equations published in the literature (Coe, 1972; Anon, 1974; Anon, 1986; Grela and Mazur, 2002). An essential achievement of the carried out tests and analyses is presentation of $\mathrm{HDgl}=\mathrm{f}(\mathrm{HDme})$ function in the 35 to $80 \mathrm{ml} / 100 \mathrm{~g}$ range, which has not been published so far.

It is worth mentioning that relationship between primary method (mercury) and any secondary method (gas chromatography, hot extraction, laser ablation) for diffusible hydrogen content in deposited metal over $31 \mathrm{ml} / 100 \mathrm{~g}$ is not described anywhere in literature. Mentioned above high temperature methods have high measurement accuracy (close to mercury method accuracy) that is why it is recommended to perform calibration of those methods also for high-hydrogen welding processes.
TABLE 5. Calculation of the raw residual values for model

\begin{tabular}{lccc}
\hline $\mathbf{N}^{\circ}$ & $\begin{array}{c}\text { HDme* } \\
(\mathbf{m l} / \mathbf{1 0 0} \mathbf{g})\end{array}$ & $\begin{array}{c}\text { HDmep**} \\
(\mathbf{m l} / \mathbf{1 0 0} \mathbf{g})\end{array}$ & $\begin{array}{c}\text { Raw residuals HDme- } \\
\text { HDmep (ml/100 g) }\end{array}$ \\
\hline 1 & 36.75 & 38.15 & -1.40 \\
2 & 48.40 & 52.85 & -4.45 \\
3 & 49.24 & 53.61 & -4.37 \\
4 & 60.40 & 60.02 & 0.38 \\
5 & 79.09 & 73.77 & 5.32 \\
6 & 47.86 & 50.07 & -2.21 \\
7 & 39.75 & 41.81 & -2.06 \\
8 & 77.98 & 74.24 & 3.74 \\
9 & 6.53 & 7.94 & -1.41 \\
10 & 12.51 & 10.07 & 2.44 \\
11 & 15.92 & 18.04 & -2.12 \\
12 & 6.08 & 4.62 & 1.46 \\
13 & 8.21 & 11.65 & -3.44 \\
14 & 22.42 & 17.38 & 5.04 \\
15 & 7.12 & 5.38 & 1.74 \\
16 & 14.21 & 11.46 & 2.75 \\
17 & 29.56 & 30.96 & -1.40 \\
\hline
\end{tabular}

*Observed diffusible hydrogen content, **Predicted diffusible hydrogen content.

\section{CONCLUSIONS}

- An expression of relation has been developed between results of the diffusible hydrogen content in deposited metal, obtained by the glycerin method and mercury method in the up to $80 \mathrm{ml} / 100 \mathrm{~g}$ range of low-hydrogen and highhydrogen welding processes. The developed formula is of linear character and in the up to $35 \mathrm{ml} / 100 \mathrm{~g}$ range gives a similar picture to the expressions described in the literature.

- Comparison of the results obtained with the discussed methods shows that in the high-hydrogen processes the glycerin method, easier to perform, may be used, but low diffusible hydrogen content in deposited metal should be determined with the mercury method because of its high accuracy.

- Conversion of hydrogen content values obtained by glycerin and mercury methods up to $80 \mathrm{ml}$ per $100 \mathrm{~g}$ in deposited metal considerably simplifies steel weldability investigations with the use of high-hydrogen processes and in water environment.

\section{REFERENCES}

Anon. (1974). Relation between hydrogen contents by IIW and JIS method. International Institute of Welding, Document IIW Doc. II-698-74.

Anon. (1986). Method of measurement for hydrogen evolved from steel welds. International Institute of Welding, Document IIW Doc. II-1073-86. 
BN-64/4130-01 (1971). Oznaczanie całkowitej zawartości wodoru w stopiwie stalowych elektrod z otuliną kwaśną, rutylową i zasadową.

Coe, F.R. (1972). The comparison of hydrogen levels. International Institute of Welding Document IIW Doc. II-A-305-1972.

Fydrych, D., Łabanowski, J. (2012). Determining diffusible hydrogen amounts using the mercury method. Weld. Int. 26(9), 697-702. http://dx.doi.org/10.1080/09507116.2011. 592682.

Fydrych, D., Łabanowski, J., Rogalski, G. (2013). Weldability of high strength steels in wet welding conditions. Pol. Marit. Res. 20 (2), 67-73. http://dx.doi.org/10.2478/pomr2013-0018.

Grela, P., Mazur, M. (2002). Comparison investigations of hydrogen diffusing from weld deposit determined by glycerin and mercury methods. Institute of Welding Bulletin 46, 54-55.

ISO 3690 (2012). Welding and allied processes. Determination of hydrogen content in arc weld metal.

Kannengiesser, T., Tiersch, N. (2010). Comparative study between hot extraction methods and mercury method-A national round robin test. Weld. World 54 (5), R108-R114. http:// dx.doi.org/10.1007/BF03263496.

Karkhin, V.A., Levchenko, A.M. (2008). Computer-aided determination of diffusible hydrogen in deposited weld metal. Weld. World 52 (2), 3-11. http://dx.doi.org/10.1007/ BF03266624

Kotecki, D.J. (1992). Hydrogen reconsidered. Weld. J. 71 (8), $35-43$.

Kotecki, D.J. (1994). Aging of welds for hydrogen removal. Weld. J. 73 (6), 75-79.

Kozak, T. (2011). Resistance to cold cracking of welded joints made of P460NL1 steel. Adv. Mater. Sci. 11 (3), 20-27. http://dx.doi.org/10.2478/v10077-011-0014-8.

Kühn, S., Unterumsberger, F., Suter, T., Poh, M. (2013). New methods for analysis of diffusible hydrogen in high-strength steels. Materials Testing 55 (9), 648-652. http://dx.doi.org/ $10.3139 / 120.110483$.

Kurji, R., Coniglio, N. (2015). Towards the establishment of weldability test standards for hydrogen-assisted cold cracking. Int. J. Adv. Manuf. Tech. 77 (9), 1581-1597. http://dx.doi. org/10.1007/s00170-014-6555-3.

López, F.A., Sierra, M.J., Rodríguez, O., Millán, R., Alguacil, F.J. (2014). Non-isothermal kinetics of the thermal desorption of mercury from a contaminated soil. Rev. Metal. 50 (1), e001. http://dx.doi.org/10.3989/revmetalm.001.

López, F.A., Alguacil, F.J., Rodríguez, O., Sierra, M.J., Millán, R. (2015). Mercury leaching from hazardous industrial wastes stabilized by sulfur polymer encapsulation. Waste Manage. 35, 301-306. http://dx.doi.org/10.1016/j.wasman. 2014.10.009.

Padhy, G.K., Ramasubbu, V., Albert, S.K., Murugesan, N., Ramesh, C. (2012). Hot extraction of diffusible hydrogen and its measurement using a hydrogen sensor. Weld. World 56 (7), 18-25. http://dx.doi.org/10.1007/BF03321361.

Padhy, G.K., Komizo, Y. (2013). Diffusible hydrogen in steel weldments -a status review. Transactions of JWRI 42, $39-62$.

Padhy, G.K., Ramasubbu, V., Parvathavarthini, N., Wu, C.S., Albert, S.K. (2015a). Influence of temperature and alloying on the apparent diffusivity of hydrogen in high strength steel. Int. J. Hydrogen Energ. 40 (20), 6714-6725. http:// dx.doi.org/10.1016/j.ijhydene.2015.03.153.

Padhy, G.K., Ramasubbu, V., Albert, S.K. (2015b). Rapid determination of diffusible hydrogen in steel welds using a modified gas chromatography facility. J. Test. Eval. 43 (1), 69-79. http://dx.doi.org/10.1520/JTE20130077.

Pańcikiewicz, K., Zielińska-Lipiec, A., Tasak, E. (2013). Cracking of high-strength steel welded joints. Adv. Mater. Sci. 13 (3), 76-85. http://dx.doi.org/10.2478/adms-2013-0013.

Pokhodnya, I.K., Yavdishchin, I.R., Paltsevich, A.P., Shvachko, V.I., Kotelchuk, A.S. (2004). Metallurgy of arc welding. Interaction metal with gases. Naukova Dumka, Kiev.

Quintana, M.A. (1984). A critical-evaluation of the glycerin test. Weld. J. 63 (5), 141-149.

Stanisz, A. (2007). The accessible course of statistics with applying STATISTICA PL using the examples from medical science. Linear and non-linear models. Vol. II., StatSoft, Poland.

Ström, C., Elvander, J. (2004). Calibration and verification of the hot extraction method including a comparison with the mercury method. International Institute of Welding Document IIW Doc. II-1543-04.

Świerczyńska, A., Fydrych, D., Łabanowski, J. (2012). The effect of welding conditions on diffusible hydrogen content in deposited metal. Solid State Phenom. 183, 193-200. http:// dx.doi.org/10.4028/www.scientific.net/SSP.183.193. 